\title{
Searching for Targets: The Power of Somatic Cell Genetics
}

\author{
Thea D. Tlsty' \\ Department of Pathology, UCSF Comprehensive Cancer Center, University of California at San Francisco, San \\ Francisco, California 94143-0506, USA
}

he efficacy of a therapeutic drug is measured by its potency and selectivity. Therefore, an important aspect of any new therapeutic approach for the treatment of cancer is the identification of traits that distinguish the normal cells of the body from the tumor cells. Modern molecular genetics has developed powerful methods for distinguishing mutant cells from nonmutant cells, even unmasking silent mutations under conditions that provide a selective advantage. The application of these genetic approaches to the design of new therapies holds tremendous potential.

In yeast genetic studies, a synthetic lethal screen allows the identification of secondary mutations that, under a specified set of genetic conditions, confer lethality (Bender and Pringle 1991). The secondary mutation in and of itself is not lethal to the organism. Synthetic lethal mutations often identify genes that have an additive effect in incapacitating a single biochemical pathway or, alternatively, genes that incapacitate two independent but functionally overlapping pathways. Using this conceptual groundwork, chemicals and other agents can be substituted for the mutational events in providing the selection pressure. In this issue, Simons et al. (2001) describe a system for screening cultured human cells for events that confer chemical synthetic lethality.

The basis of the screen described in the current report emerges from previous efforts to hone somatic cell genetics by multiple laboratories coupled with

\footnotetext{
'Corresponding author.

E-MAIL ttlsty@itsa.ucsf.edu; FAX (415) 5026163.

Article and publication are at www.genome.org/cgi/ doi/10.1101/gr.177101.
}

the application of a rapid, highthroughput detection system. The manipulation of the biosynthetic pathway for production of guanosine monophosphate (GMP) has often been used in mammalian selection studies (Benedict et al. 1984) and was chosen for this screen. To establish and validate the use of a chemical synthetic lethality screen in cultured human cells, several steps were required. First, it was necessary to refine a fluorescent detection system to monitor the retention or loss of the gene of interest (i.e., the gene that allows survival, in this case hypoxanthineguanine phosphoribosyl transferase, HPRT1). Under nonselective conditions (i.e., no secondary mutation or exposure to drug), the Epstein-Barr virus-based plasmid carrying HPRT1 and a fluorescent marker is gradually lost during cell proliferation, with a corresponding decrease in the fluorescence ratio. This was verified by independent means. However, under selective conditions where the gene of interest is needed for survival, the fluorescence ratio was demonstrated to remain high. The selection pressure for retention of HPRT1 was generated using metabolic inhibitors; both non-nucleoside inhibitors and nucleoside analogs gave satisfactory results. Finally, the screen was applied in a blind test to determine if wells containing the known inhibitors could be distinguished from those without. In this final step, a false positive rate of $1 / 600$ was calculated. The rate of false positives should reflect (1) the instability of the plasmid, (2) the strength of the selection pressure, and (3) the frequency of confounding secondary mutations.

As noted by the Simons et al. (2001), the application of the basic screening system can be extended to screening conditions that use a variety of "interrogators" in place of the chemical agents, which will increase the power of the method immensely. Whereas the original synthetic lethal screens were used to detect genetic mutations, current molecular techniques have expanded the utility of this method through the use of libraries containing antisense RNA (Deiss and Kimchi 1991; Gudkov et al. 1993), truncated cDNA (Gudkov et al. 1993), ribozymes (Breaker and Joyce 1994), RNA aptamers (Thomas et al. 1997), or peptide aptamers (Colas et al. 1996; Geyer et al. 1999). The approaches have the benefit of providing potentially novel therapeutic agents for immediate evaluation in a clinical setting.

The use of rapid, powerful genetic methods to screen mammalian cells for therapeutic agents in the treatment of cancer will become increasingly important for a variety of reasons. Several of the most important reasons are related to the nature of tumor cells themselves, i.e., the existence of multistep, interacting pathways and the abnormally high generation of genetic diversity. In any cell, there are multiple events that have the potential to inactivate any given biochemical pathway. Targeting each deficient molecule is ineffective and can easily be overcome by the continuing evolution of the tumor cell in vivo. This biological principle is the basis of drug resistance in present chemotherapeutic efforts.

On the other hand, targeting the functional endpoint of a biochemical pathway-the relevant tumor phenotype-has several benefits. First, the nature of the mutation need not be known 
beforehand. The screen simply searches for the molecule that will give the desired phenotype. This approach has the potential to uncover previously unknown molecules or pathways that are involved in the generation of that phenotype. Second, utilization of a genetic screen allows the cell to do the majority of the work in identifying multiple, relevant molecules. In addition, whereas early studies examine the tumor cell to the exclusion of its environment, future studies may tailor the screening process to allow the evaluation of microenvironmental influences as well. Finally, the coupling of these techniques with rapid detection methods will allow the timely evaluation of large libraries of compounds that may be used therapeutically. The application of time-honored genetic techniques to the identification and isolation of useful therapeutic agents is now possible and hopefully will generate new agents, which allow the treatment of cancer.

\section{REFERENCES}

Bender, A. and Pringle, J.R. 1991. Mol. Cell. Biol. 11: 1295-1305.

Benedict, W.F., Weissman, B.E., Mark, C., and Stanbridge, E.J. 1984. Cancer Res. 44: 3471-3479.

Breaker, R.R. and Joyce, G.F. 1994. Trends Biotechnol. 12: 268-275.

Colas, P., Cohen, B., Jessen, T., Grishina, I.,
McCoy, J., and Brent, R. 1996. Nature 380: $548-550$

Deiss, L.P. and Kimchi, A. 1991. Science 252: 117-120.

Geyer, C.R., Colman-Lerner, A., and Brent, R. 1999. Proc. Natl. Acad. Sci. 96: 8567-8572.

Simons, A., Dafni, N., Dotan, I., Oron, Y., and Canaani, D. Genomics Res. 11: 266-273.

Hartwell, L.H., Szankasi, P., Roberts, C.J., Murray, A.W., and Friend, S.H. 1997. Science 278: 1064-1068.

Gudkov A.V., Zelnick, C.R., Kazarov, A.R., Thimmapaya, R., Suttle, D.P., Beck, W.T., and Roninson, I.B. 1993. Proc. Natl. Acad. Sci. 90: 3231-3235.

Thomas M., Chedin, S., Carles, C., Riva, M., Famulok, M., and Sentenac, A. 1997. J. Biol. Chem. 272: 27980-27986. 


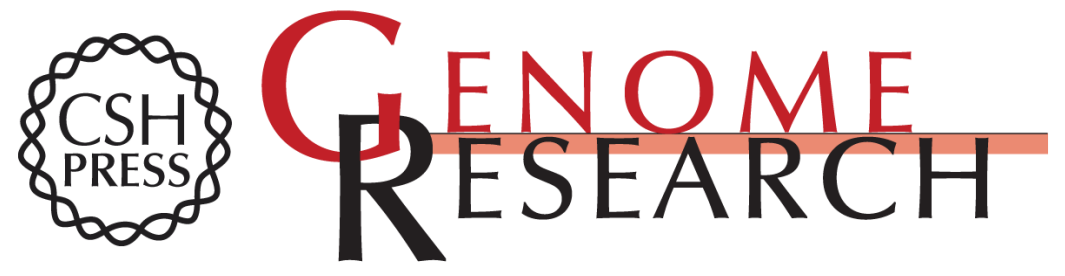

\section{Searching for Targets: The Power of Somatic Cell Genetics}

Thea D. Tlsty

Genome Res. 2001 11: 187-188

Access the most recent version at doi:10.1101/gr.177101 $\begin{array}{ll}\text { References } & \begin{array}{l}\text { This article cites } 9 \text { articles, } 7 \text { of which can be accessed free at: } \\ \text { http://genome.cshlp.org/content/11/2/187.full.html\#ref-list-1 }\end{array}\end{array}$

\section{License}

Email Alerting Receive free email alerts when new articles cite this article - sign up in the box at the Service top right corner of the article or click here.

\section{Affordable, Accurate Sequencing.}

To subscribe to Genome Research go to: https://genome.cshlp.org/subscriptions 